\title{
Neonatal small left colon syndrome
}

\author{
Zhi Lin Kang, Krishna Gopagondanahalli Revanna, Abdul Alim Abdul Haium, \\ Bhavani Sriram
}

Department of Neonatology, KK Women's and Children's Hospital, Singapore, Singapore

\section{Correspondence to}

Dr Abdul Alim Abdul Haium, drabdulhaium@yahoo.co.uk

Accepted 18 September 2015

\section{CrossMark}

\section{To cite: Kang ZL,} Revanna KG, Abdul Haium AA, et al. BMJ Case Rep Published online:

[please include Day Month

Year] doi:10.1136/bcr-2015211228

\section{DESCRIPTION}

A female baby, second of a monochorionic diamniotic pregnancy was born at 34 weeks of gestation via vaginal delivery. Birth weight was $2400 \mathrm{~g}$. During the antenatal period mother had gestational diabetes requiring insulin therapy. The baby was admitted to neonatal unit for continuous positive airway pressure support for respiratory distress, which had improved within $4 \mathrm{~h}$.

At around $24 \mathrm{~h}$ of life she was noted to have large amount of non-bilious gastric aspirates and abdominal distension. An abdominal X-ray showed dilated bowel loops and absent rectal gas. Contrast enema revealed a small calibre of the descending and sigmoid colon until the splenic flexure, dilated transverse and ascending colon which was consistent with a diagnosis of neonatal small left colon syndrome (NSLCS) (figure 1). The baby passed a thick mucus plug with a large amount of meconium after contrast enema. Subsequently she was able to tolerate the enteral feeds with spontaneous bowel opening. She was well on follow-up at 1 year of age with regular bowel opening and growth.

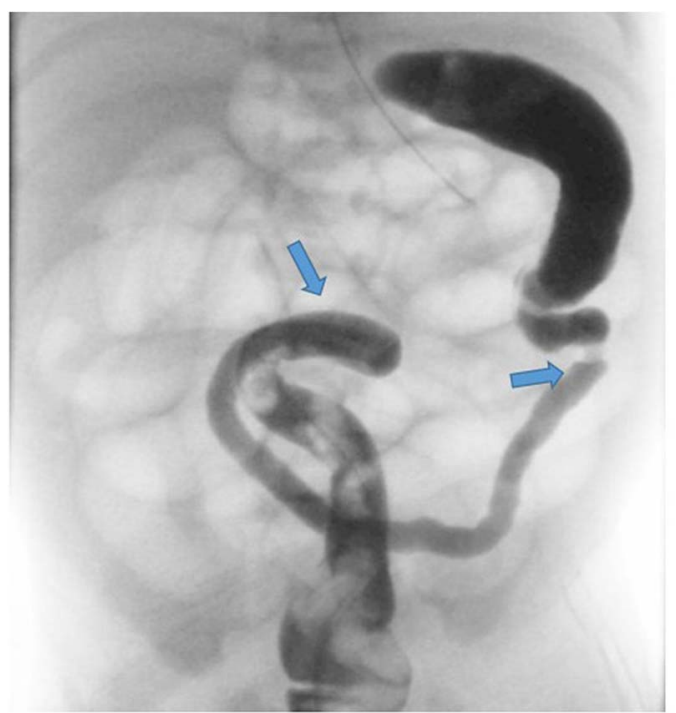

Figure 1 Water soluble contrast enema image showing characteristic narrowing of descending and sigmoid colon.
NSLCS was first coined in 1974 by Davis et al,${ }^{1}$ $40-50 \%$ of them are associated with maternal gestational diabetes. Usual presentation is failure to pass meconium, progressive abdominal distension, vomiting and high gastric aspirates. On contrast enema a narrowed descending and sigmoid colon with a transition point at the splenic flexure is characteristic and helps to differentiate from other cause of intestinal obstruction like meconium plug, Hirschprung's disease. ${ }^{2}$ Most cases resolve spontaneously, however rare late complications include peritonitis and bowel perforation especially at caecum. $^{3}$

\section{Learning points}

- Neonatal small left colon syndrome (NSLCS) should be considered as differential for neonatal intestinal obstruction especially with a background of maternal diabetes mellitus.

- Contrast enema is usually diagnostic and therapeutic.

- NSLCS has a favourable prognosis but needs close follow-up in view of late complications.

Contributors BS conceptualised the case report and helped in literature review. ZLK prepared the initial manuscript, performed the initial literature review. KGR and AAAH contributed to literature review and final editing of the manuscript. All the others were involved in the clinical management of the patient.

Competing interests None declared.

Patient consent Obtained.

Provenance and peer review Not commissioned; externally peer reviewed.

\section{REFERENCES}

1 Davis WS, Allen RP, Favara BE, et al. Neonatal small left colon syndrome. Am J Roentgenol Radium Ther Nucl Med 1974;120:322-9.

2 Ellis $H$, Kumar R, Kostyrka B. Neonatal small left colon syndrome in the offspring of diabetic mothers - an analysis of 105 children. J Pediatr Surg 2009;44:2343-6.

3 Philippart Al, Reed JO, Georgeson KE, et al. Neonatal small left colon syndrome: intramural not intraluminal obstruction. J Pediatr Surg 1975;10:733-40. 
Copyright 2015 BMJ Publishing Group. All rights reserved. For permission to reuse any of this content visit http://group.bmj.com/group/rights-licensing/permissions.

BMJ Case Report Fellows may re-use this article for personal use and teaching without any further permission.

Become a Fellow of BMJ Case Reports today and you can:

- Submit as many cases as you like

- Enjoy fast sympathetic peer review and rapid publication of accepted articles

- Access all the published articles

- Re-use any of the published material for personal use and teaching without further permission

For information on Institutional Fellowships contact consortiasales@bmjgroup.com

Visit casereports.bmj.com for more articles like this and to become a Fellow 